\title{
Conditions for Oral Health in Patients with Autism
}

\author{
Condiciones de Salud Oral en Pacientes con Autismo
}

\begin{abstract}
Lívia Tiemi Yahagi Rêgo Gonçalves*; Flavia Yumi Yahagi Rêgo Gonçalves*; Brenna Magdalena Lima Nogueira**; Ricardo Roberto de Souza Fonseca ${ }^{* \star *}$; Sílvio Augusto Fernandes de Menezes ${ }^{* * * *}$; Patrícia de Almeida Rodrigues da Silva e Souza ${ }^{* * * * * *} \&$ Tatiany Oliveira de Alencar Menezes ${ }^{* * *+* k *}$
\end{abstract}

GONÇALVES, L. T. Y. R.; GONÇALVES, F. Y. Y. R.; NOGUEIRA, B. M. L.; FONSECA, R. R. S.; DE MENEZES, S. A. F.; DA SILVA E SOUZA, P. A. R. \& MENEZES, T. O. A. Conditions for oral health in patients with autism. Int. J. Odontostomat., 10(1):93-97, 2016.

ABSTRACT: Autism is characterized as a behavioral disorder. The autistic patient has some difficulties with common life routines, such as oral hygiene and also improper diet. As a consequence the refusal of physical contact, the implementation of brushing and flossing by caregivers is difficult. The present study aimed to conduct an epidemiological study of autistic patients in treatment at the Rehabilitation Center and Neurological Organization in North of Brazil, adopting the CPO-D and ceo-d. The clinical examination has been performed with the patient sitting in chairs, at the Rehabilitation Centre itself, under artificial fluorescent light intended for room lighting. From 26 patients included in the study, $76.9 \%$ of subjects were male with a mean age of 13 years. Fifty percent had caries, and $11.5 \%$ had lesions on the gums. The mean ceo-d of children $2-$ 8 years was 0.67 . In patients $10-15$ years and $20-40$ years, the mean CPO-D was 0.70 , and 3.00 , respectively. From the study, the most significant data, seen was that half of autistic patients had carious lesions. It is vital to improve oral health conditions in these patients and by using preventive dentistry, analyze their susceptibility to oral diseases.

KEY WORDS: autistic disorder, oral manifestations, dental caries.

\section{INTRODUCTION}

Autism is characterized as a behavioral disorder, manifesting in the first three years of life persisting into adulthood. The degree of severity is associated with $I Q$, ranging from moderate to severe. This variation in the expression of symptoms, which can be mild to severe, should be considered when planning a treatment, since individuals with autism each have different abilities and behaviors from one another, so each individual has their own needs (Boyd et al., 2008; Chan et al., 2014).

The clinical features of autism, one can list the presence of deviations in social development, which is manifested by difficulties in approximation, as well as lack of eye contact and facial response, indifference or aversion to physical contact (Boyd et al.; Chan et al.; Weil \& Inglehart, 2012; Queiroz et al., 2014). It affects about four times as many men as compared to women, may be present in any individual (Jaber, 2011).

The autistic patient has some difficulties in common activities of daily life, such as oral hygiene and also improper diet. As a result in the rejection of physical contact, the execution of brushing and flossing by caregivers is difficult. However, despite poor oral hygiene and lack of facial musculature of these patients, the dental facials features such as caries and periodontal index issue, does not differ from normal patients (Russel et al., 2014; Blomqvisi et al., 2015).

Degree in Dentistry, School of Dentistry, Federal University of Pará, Belém, Brazil.

** Speech Therapist, School of Speech Therapy - University of Pará, Belém, Brazil.

*** Endodontics Department, Graduate Program in Clinical Dentistry, Faculty of Dentistry, Federal University of Pará, Belém, Brazil.

Dental Student, Para State Universit Center, Belém, Brazil.

Department of Periodontology, Para State University Center, Belém, Brazil.

Department of Endodontics, School of Dentistry, Federal University of Pará, Belém, Brazil.

${ }^{* * t+x+* * *}$ Department Patients with Special Needs, School of Dentistry, Federal University of Pará, Belém, Brazil. 
The studies about oral health and dental needs for people with autism individuals are scarce. But it is known that, although patients with behavioral changes, and therefore present difficulties in cleaning the oral cavity, oral reports of clinical manifestations in autistic patients, regarding the involvement of caries and periodontal disease are no different from normal patients (Bertoglio \& Hendren, 2009; Hernandez \& Ikkanda, 2011; Orellana et al., 2012). Therefore, knowledge of the dentist should not only be related to the nature of the physical, intellectual, emotional and/or social aspects. Success in dental treatment is linked to the knowledge of the pathogenesis of oral diseases and available resources for prevention and control. Reliable information to treat the disease, identifying risk regarding the condition is also important, as caries and periodontal disease are frequent and are caused by the deficiency in brushing (Rapin \& Tuchman, 2008; Zwaigenbaum et al., 2009; Gomot \& Wicker, 2012).

Based on these, the present study aimed to carry out an epidemiological survey in autistic individuals under treatment at the Rehabilitation and Neurological Organization Center in Northern Brazil, adopting the DMF-D and DMF-d, thus contributing to the supply of data on oral situation, in order to allow for comparisons and future planning of dental care with early interventionpossibilities and host of autistic individuals.

\section{MATERIAL AND METHOD}

The research was previously submitted to the Ethics Committee in Research of the Institute of Health and Sciences of the Federal University of Para (ICS-UFPA), registered under number 813782.

The study included patients diagnosed with autism at any age, of both sexes. Autistic patients underwent clinical examination performed with the patient sitting on chairs in the Rehabilitation Centre itself, under artificial fluorescent light intended for lighting the room on the day and time that patients had rehabilitation care.

All the information was collected by a single investigator with the monitoring and the assistance of a speech therapist. In some cases, for intra-oral clinical examination, it was necessary to use mouth openers, spatulas made of wood and lint.
The data were described in a dental chart and noted if there were any changes to the level of soft and periodontal tissue. The index used to assess oral health was the DMF-T and dmf- t.

Data were recorded in Microsoft $₫$ Office Excel $($ 2010 software, where a database was set up. The descriptive statistics of the study in tables and graphic from the calculation of frequencies have been prepared (categorical variables) and measures of central tendency and dispersion (mean and standard deviations of the quantitative variables).

\section{RESULTS}

Twenty-six patients with autism were evaluated in the study, $76.9 \%$ of subjects were male and $23.1 \%$ to females, aged 2 to 40 years (Table I).

Regarding oral manifestations in these patients, it was found that $50 \%$ had caries lesions, and $11.5 \%$ had lesions in the gums, and other mouth areas there were no changes (Table II).

For analysis of dental caries, average dmf-t of children $2-8$ years was 0.67 . In individuals $10-15$ years and $20-40$ years, the average DMF-T was 0.70 , and 3.00 , respectively.

Table I. Demographic distribution of patients Autism Spectrum Disorder.

\begin{tabular}{llcc}
\hline Variable & & Fa & Fr (\%) \\
\hline Sex & Male & 20 & 76.9 \\
& Female & 6 & 23.1 \\
Age & 2 a 8 years & 9 & 34.6 \\
& 10 a 15 years & 10 & 38.5 \\
& 20 a 40 years & 7 & 26.9 \\
Total & & 26 & 100.0 \\
\hline
\end{tabular}

Source: Research Protocol.

Table II. Prevalence of oral manifestations in autistic patients.

\begin{tabular}{llcc}
\hline Variables & & Fa & Fr (\%) \\
\hline Dental Caries & Present & 13 & 50 \\
\multirow{2}{*}{ Gingival Bleeding } & Absent & 13 & 50 \\
& Present & 3 & 11.5 \\
Total & Absent & 23 & 88.5 \\
& & 26 & 100.0 \\
\hline
\end{tabular}

Source: Research Protocol. 
GONÇALVES, L. T. Y. R.; GONÇALVES, F. Y. Y. R.; NOGUEIRA, B. M. L.; FONSECA, R. R. S.; DE MENEZES, S. A. F.; DA SILVA E SOUZA, P. A. R. \& MENEZES, T. O. A. Conditions for oral health in patients with autism. Int. J. Odontostomat., 10(1):93-97, 2016.

Table III. Average (Mean), standard deviation (SD) and relative frequency (\%) of ceo-d index (2 a 8 years), DMF-D (other groups) and ratio of the components in relation to dmf/DMF total according to age group.

\begin{tabular}{|c|c|c|c|c|c|c|c|c|c|c|c|}
\hline \multirow{2}{*}{ Age } & \multirow{2}{*}{$\mathbf{n}$} & \multicolumn{2}{|c|}{ Decayed } & \multicolumn{2}{|c|}{ Filled / Decayed } & \multicolumn{2}{|c|}{ Filled } & \multicolumn{2}{|c|}{ Missing } & \multicolumn{2}{|c|}{ dmf-t / DMF-T } \\
\hline & & Mean & $\%$ & Mean & $\%$ & Mean & $\%$ & Mean & $\%$ & Mean & SD \\
\hline 2 a 8 & 9 & 0.56 & 83.3 & 0.00 & 0.0 & 0.11 & 16.7 & 0.00 & 0.0 & 0.67 & 1.12 \\
\hline 10 a 15 & 10 & 0.70 & 100.0 & 0.00 & 0.0 & 0.00 & 0.0 & 0.00 & 0.0 & 0.70 & 1.06 \\
\hline 20 a 40 & 7 & 1.57 & 52.4 & 0.14 & 4.8 & 1.00 & 33.3 & 0.29 & 9.5 & 3.00 & 2.31 \\
\hline
\end{tabular}

As the percentage composition of the dmf-t and DMF-T indices, $83.3 \%$ of children $2-8$ years had decayed teeth condition and $16.7 \%$ the restored teeth condition. All individuals in the age group 10-15 years had the decayed teeth condition. And in adults $20-40$ years it was observed that $52.4 \%$ had a decayed teeth condition, $4.8 \%$ had decayed and filled teeth, $33.3 \%$ had filled teeth, and $9.5 \%$ had lost some teeth (Table III).

\section{DISCUSSION}

The number of people diagnosed with autism has increased significantly in the last few years (Russel et al.; Blomqvisi et al., 2015; Rapin \& Tuchman). Due to its high prevalence it becomes important in this context the participation and knowledge of its peculiarities, as well as alternative methods of treatment by the dentist (Gomot \& Wicker; Zwaigenbaum et al.).

The study group showed a high prevalence of autistic individuals were male $(76.9 \%)$ compared to females $(23.1 \%$ ), according to several authors (Chan et al.; Orellana et al.; Murshid, 2005; Jaber; Richa et al., 2014; Baron-Cohen et al., 2011) that suggested that there are differences between the functioning of the male brain, more systematic and female brains, more empathetic. Accordingly, autism would be a hyper masculinization brain (brain male extreme) and one of its causes could be early exposure to androgens such as testosterone, affecting brain development and behavior. This would explain the higher prevalence in men (Baron-Cohen et al.).

The average age was 13 years with higher caries prevalence in the age group between $20-40$ years. This finding is justified by some authors (Blomqvist et al., 2011; Delli et al., 2013) that by emphasizing that when the family receives the diagnosis of autism it also receive guidance on the therapies needed for better social and cognitive development of children and oral health care (Hernandez \& Ikkanda; Bertoglio \& Henren; Zwaigenbaum et al.; Queiroz et al.; Jaber). Other authors suggest that carious lesions are overlooked by family members until they are in an advanced process, when they cause pain and may require hospitalization for general anesthesia tobe carry out the treatment. This form of neglect can also lead to a loss of dental pieces.

Conflicting results can be observed in relation to oral health (Chan et al.; Orellana et al.; Richa et al.; Baron-Cohen et al.), where low prevalence of caries in autistic individuals is not found nor there are significant differences in the prevalence of dental caries and periodontal disease compared to non-autistic individuals. However, a high prevalence of caries in the population, has been reported by other authors (Jaber; Richa et al.; Chan et al.) probably by cariogenic diet, difficulties in performing oral hygiene, as changes have to be coordinated and there is little cooperation to carry out the tasks.

In this study, the average dmft in children 2-8 years was only 0.67 , which is considered acceptable according to the target set by World Health Organization (WHO) $(50 \%$ of children at 5 years of age free of caries). This finding may be related to the fact that they are institutionalized individuals receiving guidance and greater health care in general, corroborating another study (Orellana et al.), that evaluated the oral manifestations in institutionalized autistic individuals.

Although the rates of periodontal disease are not alarming in autism, there is no doubt that prevention is essential and all efforts should be directed to oral hygiene instructions are assimilated by patients and/ or caregivers (Lai et al., 2012; Hesselmark et al., 2015; Delli et al.). In this study, periodontal probings were not conducted, but the presence of spontaneous gingival bleeding was observed in $11.5 \%$ of autistic individuals evaluated, which can be explained by high levels of plaque found in these patients. 
Undoubtedly the participation of families and caregivers is essential in maintaining the oral health of autistic patients, but such participation should not be focused on the curative dental treatment but preventive. It should be noted that autism presents several obstacles that hinder the dental approach, although there are many alternatives to facilitate this relationship, including care in hospital (Murshid, 2005; Loo et al., 2008; Hesselmark et al.; Stein et al., 2011; Delli et al.).

\section{CONCLUSION}

From the survey conducted, it can be seen that half of autistic patients had carious lesions. It is vital to improve oral conditions in these patients either by the application of preventive dentistry, or even analysis of the susceptibility to oral diseases. This way, the number of invasive dental interventions will tend to decrease, beyond the elimination of factors such as pain and turmoil, improving the quality of life of these patients.

GONÇALVES, L. T. Y. R.; GONÇALVES, F. Y. Y. R.; NOGUEIRA, B. M. L.; FONSECA, R. R. S.; DE MENEZES, S. A. F.; DA SILVA E SOUZA, P. A. R. \& MENEZES, T. O. A. Condiciones de salud oral en pacientes con autismo. Int. J. Odontostomat., 10(1):93-97, 2016.

RESUMEN: El autismo se caracteriza como un trastorno conductual. El paciente autista tiene algunas dificultades en las rutinas ordinarias de la vida, tales como la higiene oral. Como consecuencia, la negativa al contacto físico, la implementación del cepillado y uso de hilo dental es difícil para los cuidadores. Este estudio tuvo como objetivo llevar a cabo un estudio epidemiológico de los pacientes autistas en el Centro de Rehabilitación y la organización neurológica en el norte de Brasil, adoptando el CPOD y ceod. El examen clínico se realizó con el paciente sentado en una silla en el propio Centro de Rehabilitación, bajo una luz fluorescente artificial para la iluminación de la habitación. Veintiseis pacientes fueron incluidos en el estudio, el 76,9\% de los sujetos eran varones con una edad media de 13 años con un $50 \%$ de caries, y en un $11,5 \%$ se observaron lesiones gingivales. La media ceod de los niños de 2 a 8 años fue de 0,67 . En los pacientes de $10-$ 15 años y 20-40 años, el promedio CPOD fue de 0,70 y 3,00, respectivamente. A partir del estudio se pudo determinar que la mitad de los pacientes autistas tienen caries. Es importante la educación de estos pacientes para mejorar la salud oral y la aplicación de la odontología preventiva.

PALABRAS CLAVE: trastorno autista, manifestaciones orales, caries dentales.

\section{REFERENCES}

Baron-Cohen, S.; Lombardo, M. V.; Auyeung, B.; Ashwin, E.; Chakrabarti, B. \& Knickmeyer, R. Why are autism spectrum conditions more prevalent in males? PLoS Biol., 9(6):e1001081, 2011.

Bertoglio, K. \& Hendren, R. L. New developments in autism. Psychiatr. Clin. North Am., 32(1):1-14, 2009.

Blomqvist, M.; Bejerot, S. \& Dahllöf, G. A cross-sectional study on oral health and dental care in intellectually able adults with autism spectrum disorder. B. M. C. Oral Health, 15:81, 2015.

Blomqvist, M.; Ahadi, S.; Fernell, E.; Ek, U. \& Dahllöf, G. Dental caries in adolescents with attention deficit hyperactivity disorder: a population-based follow-up study. Eur. J. Oral Sci., 119(5):381-5, 2011.

Boyd, B. A.; Conroy, M. A.; Asmus, J. M.; McKenney, E. L. W. \& Mancil, G. R. Descriptive analysis of classroom setting events on the social behaviors of children with autism spectrum disorder. Educ. Train. Dev. Disabil., 43(2):186-97, 2008.
Chan, D. F. Y.; Chan, S. H. Y.; So, H. K.; Li, A. M.; Ng, R. C. M. \& Tsang, N. Dental health of preschool children with autism spectrum disorder in Hong Kong. Hong Kong J. Pediatr., 19(3):161-8, 2014.

Delli, K.; Reichart, P. A.; Bornstein, M. M. \& Livas, C. Management of children with autism spectrum disorder in the dental setting: concerns, behavioural approaches and recommendations. Med. Oral. Patol. Oral Cir. Bucal, 18(6):e862-8, 2013.

Gomot, M. \& Wicker, B. A challenging, unpredictable world for people with autism spectrum disorder. Int. J. Psychophysiol., 83(2):240-7, 2012.

Hernandez, P. \& Ikkanda, Z. Applied behavior analysis: behavior management of children with autism spectrum disorders in dental environments. J. Am. Dent. Assoc., 142(3):281-7, 2011.

Hesselmark, E.; Eriksson, J. M.; Westerlund, J. \& Bejerot, S. Autism Spectrum Disorders and Self-reports: Testing Validity and Reliability Using the NEO-PI-R. J. Autism. Dev. Disord., 45(5):1156-66, 2015. 
GONÇALVES, L. T. Y. R.; GONÇALVES, F. Y. Y. R.; NOGUEIRA, B. M. L.; FONSECA, R. R. S.; DE MENEZES, S. A. F.; DA SILVA E SOUZA, P. A. R. \& MENEZES, T. O. A. Conditions for oral health in patients with autism. Int. J. Odontostomat., 10(1):93-97, 2016.

Jaber, M.A. Dental caries experience, oral health status and treatment needs of dental patients with autism. J. Appl. Oral Sci., 19(3):212-217, 2011.

Lai, B.; Milano, M.; Roberts, M. W. \& Hooper, S. R. Unmet dental needs and barriers to dental care among children with autism spectrum disorders. J. Autism Dev. Disord., 42(7):1294-303, 2012.

Loo, C. Y.; Graham, R. M. \& Hughes, C. V. The caries experience and behavior of dental patients with autism spectrum disorder. J. Am. Dent. Assoc., 139(11):151824, 2008.

Murshid, E. Z. Oral health status, dental needs habits and behavioral attitude towards dental treatment of a group of autistic children in Riyadh, Saudi Arabia. Saudi Dent. J., 17(3):132-9, 2005.

Orellana, L. M.; Silvestre, F. J.; Martínez-Sanchis, S.; Martínez-Mihi, V. \& Bautista, D. Oral manifestations in a group of adults with autism spectrum disorder. Med. Oral Patol. Oral Cir. Bucal, 17(3):e415-9, 2012.

Queiroz, F. S.; Rodrigues, M. M. L. F.; Cordeiro Junior, G. A.; Oliveira, A. B.; Oliveira, J. D. \& Almeida, E. R. Avaliação das condições de saúde bucal de Portadores de Necessidades Especiais. Rev. Odontol. U. N. E. S .P., 43(6):396-401, 2014.

Rapin, I. \& Tuchman, R. F. Autism: definition, neurobiology, screening, diagnosis. Pediatr. Clin. North Am., 55(5):1129-46, 2008

Russell, G.; Rodgers, L. R.; Ukoumunne, O. C. \& Ford, T. Prevalence of parent-reported ASD and ADHD in the UK: findings from the Millennium Cohort Study. J. Autism Dev. Disord., 44(1):31-40, 2014.

Stein, L. I.; Polido, J. C.; Mailloux, Z.; Coleman, G. G. \& Cermak, S. A. Oral care and sensory sensitivities in children with autism spectrum disorders. Spec. Care Dentist., 31(3):102-10, 2011.

Weil, T. N. \& Inglehart, M. R. Three- to 21-year-old patients with autism spectrum disorders: parents' perceptions of severity of symptoms, oral health, and oral health-related behavior. Pediatr. Dent., 34(7):473-9, 2012.

Richa; Yashoda, R. \& Puranik, M. P. Oral health status and parental perception of child oral health related qualityof-life of children with autism in Bangalore, India. J. Indian Soc. Pedod. Prev. Dent., 32(2):135-9, 2014.

Zwaigenbaum, L.; Bryson, S.; Lord, C.; Rogers, S.; Carter, A.; Carver, L.; Chawarska, K.; Constantino, J.; Dawson, G.; Dobkins, K.; Fein, D.; Iverson, J.; Klin, A.; Landa, R.; Messinger, D.; Ozonoff, S.; Sigman, M.; Stone, W.; TagerFlusberg, H. \& Yirmiya, N. Clinical assessment and management of toddlers with suspected autism spectrum disorder: insights from studies of high-risk infants. Pediatrics, 123(5):1383-91, 2009.

Corresponding to:

Dra. Brenna Magdalena Lima Nogueira

Endodontics Department

Graduate Program in Clinical Dentistry

Faculty of Dentistry

Federal University of Pará

Belém, PA

BRAZIL

Email: bre_nog@hotmail.com

Received: 15-11-2015

Accepted: 03-02-2016 